\title{
The Art of Protest: Understanding and Misunderstanding Monstrous Events
}

Stefan Jonsson

The self-archived postprint version of this journal article is available at Linköping University Institutional Repository (DiVA):

http://urn.kb.se/resolve?urn=urn:nbn:se:liu:diva-175187

N.B.: When citing this work, cite the original publication.

Jonsson, S., (2021), The Art of Protest: Understanding and Misunderstanding Monstrous Events, Theory \& Event, 24(2), 511-536. https://doi.org/10.1353/tae.2021.0024

Original publication available at:

https://doi.org/10.1353/tae.2021.0024

Copyright: Johns Hopkins University Press

http://www.press.jhu.edu/journals/ 


\section{The Art of Protest: Understanding and Misunderstanding Monstrous Events}

\section{Stefan Jonsson}

Final pre-print version

Jonsson, Stefan. "The Art of Protest: Understanding and Misunderstanding Monstrous Events." Theory \& Event, vol. 24 no. 2, 2021, p. 511-536. Project MUSE, doi:10.1353/tae.2021.0024.

\section{Abstract}

This essay explores the basis for dialogue at the junction of political theory, historical research and aesthetic analysis. It does so by making two claims. The first one concerns political emergence, which refers to movements that emerge outside democratic institutions and portend profound reorganizations of political order although they are not yet fully recognizable as political entities as they have weak political representation. The second claim implies that aesthetic presentations and performances (fiction, poetry, visual arts, film, theater) offer unique ways of understanding political emergence, and hence also collective protest, revolt and revolution. Artworks embody this potentiality because they register the experience of protests, not as representations of fixed historical agents, but in ways comparable to the testimonial mode of the participant and the witness in situations of social stress, struggle and political violence.

Keywords: Aesthetics, Political Theory, Theory of History, Social Movements in Art, Political Emergence, Crowd Theory, Crowds, Collectivity, Epistemology, Phenomenology, Witness literature, Aesthetic Knowledge, History of Sociology

\section{Jena 1922}

I begin on September 24, 1922. On that date, German sociologists convened in Jena under the chairmanship of Ferdinand Tönnies. Their intent was to reconstitute the German Sociological Association after World War I and assert the young discipline's continued and increasing significance; hence the convention's topic. Much had happened since the previous convention. A World War had intervened. In Russia, the Bolsheviks had taken power. In Germany, the 
aftereffects of the revolution of 1918-19 still rumbled. Europe in its entirety was shaken by rebellions and uprisings. The topic of the gathering: "The essence of revolution."1

Strangely, however, none of the sociologists in Jena mentioned the revolutionary events, the social unrest or the class struggle going on outside the conference venue. Lenin was not mentioned, nor Marx. A peculiar impartiality reigned supreme: Wertfreiheit, as Max Weber called it. German sociology of the 1920s did not deal with social reality but with the concept of society-its ideal types, categories, varieties, forms and subforms. The gathered sociologist were therefore just as silent on the causes of the recent German revolution as on its possible outcomes. Far greater was their interest in das Wesen der Revolution, the "essence of Revolution.” In order to circumscribe this essence, as Leopold von Wiese put it in his keynote address, one had to find "a pure concept of the revolution," a task which in his sober view consisted in measuring the correlation between social differentiation and social integration.

Did the social scientists of interwar Germany shoulder their historical responsibility? Posterity tends to answer no, although there were exceptions. ${ }^{2}$ Not that they prepared the way for or welcomed Nazism (although here, too, there were exceptions) but they shaped their analytical tools in such a way that they made themselves incapable of addressing the contemporary situation. Jena in 1922 is an example which illustrates how scholarship can successfully combine a high level of conceptual sophistication with near complete societal and political irrelevance.

The following pages will deal not with the "essence" of revolution, but with revolt and political protest. I will discuss how such protests are situated within our conceptual and historiographic systems of representation. I will argue that collective protest is an event that is usually expelled to a non-place of history, and I will suggest that serious consideration of aesthetic expressions of political protest may help to reinstate it to its proper place, as a pre-eminent place of modernity.

\footnotetext{
${ }^{1}$ Leopold von Wiese, "Die Problematik einer Soziologie der Revolution,” in Ferdinand Tönnies, Leopold von Wiese och Ludo Moritz Hartmann, Das Wesen der Revolution. Verhandlungen des Dritten deutschen Soziologentages am 24. und 25. September 1922 in Jena. Reden und Vorträge, Tübingen: J. C. B. Mohr, 1923. Unless stated, translations of cited sources are my own.

${ }^{2}$ Fritz K. Ringer, The Decline of the German Mandarins: The German Academic Community, 1890-1933 (Cambridge: Harvard University Press, 1969).
} 


\section{Political Emergence and Aesthetic Knowledge}

Among the sociologists in Jena in 1922 was the young Gerhard Colm. When Hitler came to power Colm found asylum in New York, where he contributed to the founding of the New School for Social Research. In a 1931 entry he wrote on "Masse" (Crowd/Mass) in a dictionary of sociology, Colm asserted that "the action of the mass is an alarm bell of history." 3 Today, the bells ring anew; like the sociologists in Jena we look out our windows to discover that we are living in an "era of crowds." World-system theorist Immanuel Wallerstein predicted in the 1990s that the first decades of our millennium would see the fall of the "crazy fantasies" of neoliberal capitalism and the coming of a "dangerous, chaotic and unpleasant time." This period would be marked by a struggle between crowds seeking to democratize society from below and authoritarian counterreactions. ${ }^{4}$ If Seattle was a first trembling of worldwide rebellions, the war on terror launched after September 11, 2001 gave a first indication of general totalitarianism with global firing power and infinite capacities of surveillance. As Wallerstein saw it, democratic institutions would be put under tremendous pressure. ${ }^{5}$

To the same effect, several political theorists argue that the future of democracy hinges on the capability of political institutions and civil society to channel and represent political passions that erupt in collective protests. As they argue, liberal parliamentary democracy may seem to work well compared to most other political systems, but only as long as socio-economic conditions are stable and the distribution of wealth reasonably equal. Such conditions failing, democracy no longer develops rationally through institutional channels but through the dynamics of social movements. ${ }^{6}$

There is by now a fair amount of scholarship - empirical and theoretical — on contemporary collective protests. This work seeks to explain collective action, crowds, populism, and revolt,

\footnotetext{
${ }^{3}$ Gerhard Colm, "Masse," in Alfred Vierkandt, ed., Handwörterbuch der Soziologie (Stuttgart: Ferdinand Enke Verlag, 1931), 358.

${ }^{4}$ Immanuel Wallerstein, Utopistics: Historical Choices of the Twenty-first Century (New York: The New Press, 1998).

${ }^{5}$ French anthropologist Alain Bertho had a similar inkling. Sensing that the 1990s entailed the start of a new political cycle of social unrest, he began to "collect" uprisings and rebellions from all around the world (Le temps des émeutes [Paris: Bayard, 2009]).

${ }^{6}$ Etienne Balibar, Violence and Civility: On the Limits of Political Philosophy, New York: Columbia University Press, 2015; Chantal Mouffe, On the Political, London: Routledge, 2005; Göran Therborn, "New Masses? Social Bases of Resistance," New Left Review II/85 (2014): 7-16.
} 
and it has also reignited a normative discussion on solidarity, equality and democracy. ${ }^{7} \mathrm{My}$ undertaking in this essay is informed by the rich, ongoing discussion of the causes and consequences of contemporary social protest, but it is also prompted by a sense that current social sciences offer at best a limited understanding of these upheavals. Academic specialization seems to discourage attempts to study the interdependencies between various collective protests for democratic reform from below (as in the Arab Spring and the antiausterity protests in southern Europe), and they rarely trace the relation between such movements and the wider phenomenon of populism, not to speak of right-wing or authoritarian mobilization. Meanwhile, contemporary art, literature, film, and art activism are preoccupied by the very same social and political movements. From the postcolonial novel and arts biennales to banlieue rap music and street actions for refugees, aesthetic works have in recent years produced profound insights into the nature of social protest. Of course, such works are also restricted by their conditions of production, for example, by their genre, medium, audience, and mode of address. Unlike the social sciences, however, which operate with what I will call a representational epistemology, aesthetic works illuminate the experiential level of protest, including its embodied, participatory and affective dimensions as well as its non-linear temporality.

We thus observe that there exist parallel paths for intellectual inquiry into the same urgent issues. We also observe a lack of dialogue and methodological rapport. Against this background, we surely stand to gain from an effort to conjoin social scientific research and aesthetic analysis. This essay explores the basis for such an alliance by making two claims. The first one concerns a phenomenon that I call political emergence - in part inspired by Raymond William's, Keith Sawyer's and Pierre Nora's respective elaborations of the notions of emergent cultural formations, social emergence and historical emergence. ${ }^{8}$ As a concept, political emergence refers to movements that emerge outside democratic institutions and that portend profound reorganizations of political order, but which are not yet fully recognizable as political entities as they own weak political representation.

\footnotetext{
${ }^{7}$ For overviews, see G. Marlies and G. Pleyers, "The moment of 2011," Development and Change 44/3 (2013): 547-567; Jeannie Sowers and Christ Toensing, The Journey to Tahrir: Revolution, Protest, and Social Change in Egypt (London: Verso, 2012); Andrea F. Khalil, Crowds and Politics in North Africa (London: Routledge, 2014); Fawaz A. Gerges, ed. The New Middle East: Protest and Revolution in the Arab World (Cambridge: Cambrdige University Press, 2014); and Joshua Clover, Riot, Strike, Riot: The New Era of Revolt (London: Verso, 2016).

${ }^{8}$ Raymond Williams, Marxism and Literature (Oxford: Oxford University Press, 1978); Keith R. Sawyer, "Durkheim's Dilemma: Toward a Sociology of Emergence," Sociological Theory 20/2, 2002, 227-47 and Social Emergence: Societies as Complex Systems (Cambridge: Cambridge University Press, 2005); Pierre Nora, "L'événement monstre," Communications 18 (1972): 162-72.
} 
The second claim may be evoked by three canonized lines in a poem by Adrienne Rich: "Poetry / isn't revolution but a way of knowing / why it must come."9 As I will argue, aesthetic presentations and performances offer unique ways of knowing the significance of political emergence, hence also of collective protest, revolt and revolution. To avoid misunderstanding, I should underline that I use aesthetics not in its conventional, watered-down sense, as referring to some exclusive quality or worth of certain texts, images, or objects usually called high art, but rather in its rigorous epistemological meaning: as understanding acquired through sensory perception and imagination, i.e. how we make sense of the world, how the world is made intelligible or sensible through acts of hearing and seeing, as in fiction, poetry, visual arts, film or theater, but also in masks, songs, slogans or graffiti. Such presentations enable us to comprehend political emergence because they register sociopolitical transformation through voice, embodied experience and subjective expression in ways comparable to the testimonial mode of the participant and the witness, and often in situations of social polarization and political violence. Put differently, the aesthetic act conveys political emergence and political transformation in their sensory, affective, performative, and participatory dimensions.

Perhaps, another way of saying this would be that aesthetic works can absorb the phenomenological experience generated by participation in collective protest and revolt. Yet, I am not suggesting that we simply supplement a representational perspective adopted in the social sciences by a phenomenological perspective, or a method relying on participatory phenomenology, as revealed by the arts. Phenomenological dimensions of collective protest are at the heart of my interest, to be sure. However, as an analytical approach, phenomenology entails problematical presumptions of how knowledge is produced by a subjective individual consciousness intentionally interacting with sensory stimuli and concrete phenomena of the world. This model cannot fully capture the collective experience of protest and revolt, with its assemblage of affect, embodiment, participation, dialogue, action and struggle. Hence the suggestion that an understanding of political emergence presupposes aesthetic knowledge; that is, knowledge encoded in aesthetic expressions that make sense of collective protest by attending to all the variegated components of that complex assemblage.

\footnotetext{
${ }^{9}$ Adrienne Rich, “Dreamwood,” in Time's Power: Poems 1985-1988 (New York: W. W. Norton, 1989), 35.
} 
To illustrate, aesthetic expressions of revolt may be seen as distilled expressions of "voice" in at least three different senses: first, because they presuppose a body and a subjectivity in communal dialogue with other assembled bodies and subjectivities; second, because they have a transient existence in the temporality of the here-and-now; third, because such expressions, in setting themselves apart from the event of political emergence, can endow this event with meaning, a meaning which then returns to inspire further action. In their ability to crystallize such voices in visual, plastic, poetic, rhetorical, and narrative form, aesthetic works and testimonials related to collective protest invite knowledge of at least three specific aspects of political emergence: solidarity (bodies and subjectivities being together in common), temporality (the unique here and now of a protest or revolt), and emancipation (towards free expression and agency). ${ }^{10}$ Such aesthetic articulations of solidarity, time and emancipation are historically and politically important because they provide insights into embodied, collective and agential instances of political emergence which other modes of knowledge such as sociology, political science, history and journalism cannot account for.

My argument thus concerns the capacity of aesthetic expressions to register the political emergence of collective social actors. In interrogating this problem, I must straddle a divide inherited from Romantic and modernist distinctions between the aesthetic domain and the domain of politics. ${ }^{11}$ If the walls between the domains were dismantled - which was always what radical and Marxist aesthetics was about - we would be able to discern the ability of aesthetic figuration to expose features of the democratic process that do not-and cannotreceive sufficient attention in the social sciences. Before collective actors emerge as subjects and objects of political representation they always appear as subjects of aesthetic selfpresentation through the simple fact of claiming voice and presence, by being seen and heard in the polity. ${ }^{12}$ My two claims combined into one, then, is that aesthetic mediations of the

\footnotetext{
${ }^{10}$ In this context, and as detailed below, I am inspired by Bernard E. Harcourt, W. J. T. Mitchell, and Michael Taussig, Occupy: Three Inquiries in Disobedience (Chicago: The University of Chicago Press, 2013); Furio Jesi, Spartakus: The Symbology of Revolt, ed. Andrea Cavaletti, trans. Alberto Toscano (Calcutta: Seagull Books, 2014); Katharzyna Jezierska and Lezsek Koczanowicz, eds., Democracy in Dialogue, Dialogue in Democracy (Aldershot: Ashgate, 2015); Pnina Werbner, Martin Webb and Kathryn Spellman-Poots, The Political Aesthetics of Global Protest: The Arab Spring and Beyond (Edinburgh: Edinburgh University Press, 2014); and Yates McKee, Strike Art: Contemporary Art and the Post-Occupy Condition (London: Verso, 2016).

${ }^{11}$ Andreas Huyssen, After the Great Divide (Bloomington, IN: Indiana University Press, 1987); Peter Bürger, Theorie der Avantgarde (Frankfurt am Main: Suhrkamp, 1974).

12 Jacques Rancière, The Politics of Aesthetics (London: Continuum, 2004); Hannah Arendt, The Human Condition, 2d ed. (Chicago: The University of Chicago Press, 1958).
} 
experience of political emergence give access to knowledge about political action and participation in its deepest sense. ${ }^{13}$

A final framing remark: my question has two dimensions. The first is epistemological and methodological: according to which mechanisms, or, in dialogue with Hayden White and Fredric Jameson, according to which poetics of history are collective protests transformed into historical narrative and knowledge? ${ }^{14}$ The other dimension is ethical and political. Suddenly, the square is crowded with people demanding bread and justice. Throughout the modern era and before, collective movements engaging in protest have transformed systems of governance and power. These protests ultimately address foundational democratic issues: who can speak and act on behalf of the people? Who can rightly embody the symbols of the people and stake out their destiny? The capacity of the intellectual to responsibly answer such questions depends on the "poetics" through which s/he approaches and represents collective protests.

\section{Collective Protest and the Social Sciences}

Collective protest has been subject to what historian Manfred Gailus calls a "battle of interpretations," or Deutungsstreit. ${ }^{15}$ In modern political thought the role of collective protest has been controversial: that real men and women come together and merge into a unified political subject, the people or the multitude; that this subject embodies a political principle, democracy; and that democracy takes expression in defined historical events called revolts and revolutions. All this is contested matter.

When observing such events, social researchers and journalists have often asked the same question: How is it that a number of diachronically unfolding processes, each of which comprises single persons or smaller groups, are suddenly synchronized into a larger transformation? Persons with diverging motivations converge into a single force-the sociologists of yesteryear spoke of the "activated" mass - and these people battle against police, upset political institutions and shift relations of power. Historians and journalists own an arsenal

\footnotetext{
${ }^{13}$ Mark Purcell, The Down-Deep Delight of Democracy (Chichester: Wiley-Blackwell, 2013); Jason Frank, The Democratic Sublime: On Aesthetics and Popular Assembly (Oxford: Oxford University Press, 2021).

${ }^{14}$ See Hayden White, Metahistory: The Historical Imagination in Nineteenth-Century Europe (Baltimore: The Johns Hopkins University Press, 1973); Fredric Jameson, The Political Unconscious: Narrative as a Socially Symbolic Act (Ithaca, NY: Cornell University Press, 1981).

${ }^{15}$ Manfred Gailus, "Crowds in History," in N. J. Smelser, James Wright, and P. B. Baltes, eds, International Encyclopedia of the Social \& Behavioral Sciences (New York: Pergamon, 2001), 3026.
} 
of metaphors with which they disguise their inability to understand collective protest and revolt. For instance, they frequently say that history changes direction (as if it had one) or reaches a turning point (as if it otherwise proceeded linearly). There is also frequent use of "explosions," “eruptions," "storms," "waves," typically prefixed by “popular." Or it is said-in analytical but still meaningless fashion - that quantitative changes turn into qualitative ones. If you encounter such tropes, you can be sure that historical explanation has come up against its limits. The observer switches key, shifts register, when he or she is confronted by uprisings and other forms of collective protest. Language becomes figural. The account is often invaded by emotional expressions and frozen metaphors. This brings me to a paradox that will accompany my following remarks. How to explain that the very events that in retrospect appear as historical seem to be impregnable to conventional categories of diachronic and causal analyis? Why is it, for example, that historiography often describes collective protests as taking place "outside" history, going "beyond" history or "against" history?

A first step toward answering these questions is to acknowledge that accounts of collective behavior made by historians and social scientists are usually informed by an epistemology of representation. ${ }^{16}$ It is so simple and self-evident that it often goes unnoticed. It operates under the assumption that there is a distance between the observing subject and the observed collective, the object. Due to its remoteness and its power of observation, the subject of observation experiences itself as an individual in relation to the collective that it observes. Ideas of collective behavior that rest on this structure move along a perspective line stretching from an individual's viewpoint to the "masses" filling out the field of vision. This structure usually determines how collective behavior is treated in history and sociology. In order to become the object of analysis, an event or process must first be pre-interpreted as an expression of an underlying social agent or force. In this way, history writing and sociology tend to correlate representations of social groups or demographic categories to representations of sociohistorical events, thereby construing a revolt or collective protest as a manifestation of a particular collective agent which is given a name and identified as the very cause of the historical process.

\footnotetext{
16 A point emphasized also by Leon Bramson, The Political Context of Sociology (Princeton, NJ: Princeton University Press, 1961); Susanna Barrows, Distorting Mirrors: Visions of the Crowd in Late Nineteenth-century France (New Haven, CT: Yale University Press, 1981); Etienne Balibar, La crainte des masses (Paris: Galilée, 1997); Judith Butler, Notes Toward a Performative Theory of Assembly (Cambridge: Harvard University Press, 2015). See also Stefan Jonsson, Crowds and Democracy: The Idea and Image of the Masses from Revolution to Fascism (New York: Columbia University Presss, 2013).
} 
Hence the predictability that is characteristic of many a social scientists' and historians' portraits of lower-class, subaltern or feminist protests, especially collective and spontaneous ones. "The masses are always the others," Theodor Adorno once stated as he rebuked this redundant logic of representation. ${ }^{17} \mathrm{~A}$ methodological lesson may be drawn from this: the problem of understanding collective protest does not consist of finding a correct representation of it, but in developing a method of analysis that does not recode political events as representations. ${ }^{18}$

\section{Monstrous Events}

Can we conceive of a "non-representational theory" of politics and history? Pierre Nora took interesting steps in this direction in his writings from the early 1970s on historical emergence and what he called "the monster event" (l'événement monstre). Profoundly influenced by May 1968 in France, Nora argued that mass media had deprived the historians of their object of analysis. As he explained, mass media select and focus certain items in the stream of time and transform them into "historical events," whereas everything that is not reported disappear or are at best preserved as anecdotes, or fait divers. His conclusion was dramatic: "Henceforth mass media hold the monopoly over history." 19

In this new context, the "monster event" demanded particular attention, Nora maintained. Such events were characterized by immediate dissemination and strong emotional investment. They presented themselves in multiple, ambiguous and contradictory ways and could therefore rapidly mobilize great collectives. The large demonstration, and in particular the wave of apparently unrelated demonstrations in rapid succession, was for Nora the primordial type of a monster happening. May 1968 remained his example par excellence: a series of news, protests, speeches, tones, images, sounds, eruptions, deeds, bodies, and desiring political subjects, all linked by a media logic in which each new link would reinforce the whole, the "monster," which was soon all-encompassing and inescapable. In the context of the huge demonstrations in support of the magazine Charlie Hebdo on January 11, 2015 in Paris, Pierre Nora returned to

\footnotetext{
${ }^{17}$ Theodor W. Adorno, et al., Aspects of Sociology, trans. John Viertel (London: Heinemann, 1973), 73.

${ }^{18}$ For an example of this point, see Gayatri Spivak's friendly criticism of the Subaltern Studies collective, who, in her view, fabricated a subject which was then aposteriori introduced as an underlying cause, a historical subject or subaltern consciousness, which manifested itself in the historical process; see "Introduction. Subaltern Studies: Deconstructing Historiography," in Ranajit Guha and Gayatri Chakravorty Spivak, eds, Selected Subaltern Studies (Oxford: Oxford University Press, 1988).

${ }^{19}$ Nora, "L'événement monstre," 162.
} 
his old argument about monstrous events. ${ }^{20}$ Four million on the streets! If anything, this was a monster event, prepared and presented by mass media, which also ensured that it was noted down and preserved in history books even long before the demonstration was over. On Nora's account, the monster event is an unpredictable, transient, and collective rupture in which society as in a flash of lighting becomes visible to itself. It is an image that destroys all images and thus reawakens the historical and political imagination.

What is perhaps more interesting than Nora's theoretical remarks on May 1968 and the mediation of collective protests is his choice of the term monstrous to designate such processes. To my knowledge, Nora has never really explained his choice of terminology. ${ }^{21}$ The designation is in any case a serendipitous one. Had Nora dug deeper into the archive of insurrections, he would have found the true connection between monster and collective protest or revolution.

\section{Frankenstein and the Revolution}

In the history of European imagination monstrosity has a fairly well-defined meaning. A monster is first of all a creature that demonstrates - the Latin word monstrare means "to show" or "to exhibit" - a disturbance in the order of the world. The monster operates outside the social contract, and it often demonstrates a vice that threatens the cohesion and reason of the human community. The function of the monster is thus to warn (Latin: monere) humanity of the punishment awaiting those who commit such vices.

As Chris Baldick has explained with reference to Shakespeare's plays, "it is the vices of ingratitude, rebellion, and disobedience, particularly toward parents, that most commonly attract the appellation 'monstrous': to be a monster is to break the natural bonds of obligation towards friends and especially toward blood-relations." 22 According to Baldick, it was such disobedience toward parents that Edmund Burke had in mind when he, condemning the French Revolution, extended the usage of the term monstrous so that it signified a particular social disorder. In his Letters on the Proposal for Peace with the Regicide Directory of France, Burke

\footnotetext{
${ }^{20}$ Pierre Nora, "Retour sur un événement monstre. L'avant et l'après.” Le débat, no. 185 (2015): 4-10. See also Catherine Calvet, and Cécile Daumas, 'Pierre Nora : "La manifestation du 11 janvier est le type même de l'événement monstre,", interview, Libération 20 Jan. 2015.

${ }^{21}$ The volume of collected essays in which "L'événement monstre" is republished in edited form also makes no comment on this (Pierre Nora, "Le retour de l'événement," in Présent, nation, mémoire (Paris: Gallimard, 2013).

22. Chris Baldick, "The Politics of Monstrosity," in Fred Botting, ed., Frankenstein, Mary Shelley (New York: St. Martin's Press, 1995), 51. The following account is indebted to Baldick's essay.
} 
called France a "monster of state," "the mother of monsters," "a monstrous compound," and a "cannibal republic." 23 What motivated the hysteric terminology was Burke's repugnance for the Republic's violations of the social bonds and obligations codified in the feudal tradition. The revolution was monstrous because it demonstrated an unpardonable disobedience of servants toward their masters and of children toward their parents.

When liberal writers defended the revolution against Burke they seized on the theme of monstrosity, stating that it was the monstrous injustice of the feudal system that had caused the rebellion of the French people, whose violence was thus justified. Among those who used this argument were, most famously, Mary Wollstonecraft and William Godwin, the parents of Mary Shelley, who was to write Frankenstein: or the Modern Prometheus (1818).

This debate was one of the first to pose the problem concerning the legitimacy of social change and its relation to stability and permanence. How do we judge social transformations if we are confined within a discourse of modernity that defines development as a continuous negation of the past? If change and innovation become modernity's supreme values, these values will also override all other values that might be used to measure the value of change. In the era of modernity, when the future is no longer seen as an organic outgrowth of the past, historical transformation thus becomes incalculable and enigmatic.

According to Baldick, this topic was woven into the text of Mary Shelley's Frankenstein. ${ }^{24}$ The relation between Doctor Frankenstein and his monster, the parent and his fabulous offspring, should be regarded as an allegory of Shelley's attempt to represent the connections between plans made in the present and their uncertain future results. The novel about Frankenstein's relationship to his monster thus elaborates on the relation of a historical cause to its possible effects. In Frankenstein's case, this causality can only be thought of as an absolute discontinuity, the same kind of discontinuity, that is, as the one pertaining between pre-

\footnotetext{
23. Quoted in Baldick, "Politics of Monstrosity," 56. On the relation of Burke's aesthetics and his attitude toward the French revolution, see Jason Frank, "'Delightful Horror': Edmund Burke and the aesthetics of democratic revolution," in Nicolas Kompridis, ed., The Aesthtetic Turn in Political Thought (London: Bloomsbury, 2015), 328.

${ }^{24}$ See also Peter Brooks, "What is a Monster? According to Frankenstein," in Body Work: Objects of Desire in Modern Narrative (Cambridge: Harvard University Press, 1993).
} 
revolutionary France and the first Republic. In this sense, the monster is a figure of what Jason Frank has called "the radical democratic sublime." 25

This discontinuity, then, is the sign of a failure to imagine how one society is transformed into another, to conceptualize historical change, and it makes itself felt most sharply in periods of revolution, war, and disaster, or during what Kaja Silverman has called "historical traumas."26 In Western culture, it appears as if these discontinuous events breed most if not all monsters. The monsters are the results of our failed attempts to figure out the riddle of history, or understand how one society can be qualitatively different from the preceding one. Like the spectre of communism itself, monsters emerge as substitutes for an understanding of history of which we are uncapable; their presence and agency explain, or rather explain away, what we cannot explain.

Victor Hugo was therefore wrong, writing as he once did that "monsters are the dreams of God." Monsters are the dreams of a humanity struggling to understand history, time, and change. This implies that monsters are most likely to show up in periods when history is most difficult to understand. Periods of historical trauma and sudden rupture are characterized by the absence of organizing principles of power and authority. The monster will then appear as an imaginary substitute, allowing the members of the community to believe that there is agency or rationality at work, if only of a malign and destructive kind, where in fact there may be none.

Eric Santner, who has probed more deeply than many others into riddles of political and cultural representation in times of revolution, war, and social collapse, has argued that such discontinuities often disclose a repressed truth concerning democratic sovereignty, namely the fact that it is incompatible with representational forms while at the same time expressing a deep political desire for some kind of popular representation. In his analysis of the literary expressions of the struggles over modernity and democracy in Europe around World War I, Santner discusses Franz Kafka's works as representing what he calls a "postmythic order," in which the individual no longer finds neither his place nor his future in the texture of fate. Kafka's heroes and heroines have no idea of who they are or what they are supposed to do.

\footnotetext{
${ }^{25}$ Frank, "Delightful Horror," 21 . The revolutionary crowd as a sublime being is a theme that runs thorugh Victor Hugo's novels, especially Les Misérables; see Stefan Jonsson, A Brief History of the Masses: Three Revolutions (Columbia University Press, 2008), 50-51.

${ }^{26}$ Kaja Silverman, Male Subjectivity at the Margins (New York: Routledge, 1992), 55, 401.
} 
Social processes of investiture and interpellation have collapsed; the big Other is silent; the transfer of authority from one generation to the next is broken. In Santner's view, it is this interruption of historical continuity and symbolic representation that explains all the uncanny animals that invade Kafka's stories. The disruption, the historical interval, he states, “opens up a space within which monstrosities can appear." ${ }^{27}$ As an aesthetic figure, then, the monster would be a materialization of the effusive and intangible meaning of political emergence, as displayed in protest and revolution.

In a more recent book, Santner argues that democracy has since its inception been haunted by the political theology of the monarchic system. Monarchy asserts that sovereign power can be incarnated by the body of the monarchic ruler. In the democratic age, by contrast, sovereignty is embodied by the people. However, the body of the people is a body without gestalt. It is Claude Lefort's idea that the position of power in democracy is an empty place. ${ }^{28}$ Still, each part of the plural and manifold body of the people is a member of the principle of sovereignty; as Santner states, each one is invested in power. Hence, in a democratic system, each person carries within themselves the contradiction that in the previous system characterized only the body of the monarch: each and every body has in a certain sense two bodies and is part of two orders; the sublime order of power, on the one hand, and the order of "the flesh" on the other. ${ }^{29}$

In democracy, there is therefore a chronic tension between the sovereignty principle as incarnated in the people or popular subject, and that very people's diversity of bodies, which is unable to symbolize or incarnate the sovereignty in which they are all invested. ${ }^{30}$ According to Santner, modern cultural history is largely an ongoing symbolization of the tension between the people's two bodies, one sublime because it is an emanation of the sovereign power, the other flesh, formless and deformed, because it cannot fit into any representative forms. In this view, the history of democracy is marked by a constant demand for political representation that can never be met.

\footnotetext{
${ }^{27}$ Eric L. Santner, My Own Private Germany: Daniel Paul Schreber's Secret History of Modernity (Princeton: Princeton University Press, 1996), 133.

${ }^{28}$ Claude Lefort, The Political Forms of Modern Society: Bureaucracy, Democracy, Totalitarianism, ed. John B. Thompson (Cambridge: The MIT Press, 1986).

${ }^{29}$ Eric L. Santner, The Royal Remains: The People's Two Bodies and the Endgames of Sovereignty (Chicago: The University of Chicago Press, 2011), 63-86.

${ }^{30}$ Santner, 50-62. His argument is here analogous to Pierre Rosanvallon's distinction between "the people as principle" (peuple-principe, peuple-souverain) and "the people as society" (peuple-société), albeit Rosanvallon puts stronger emphasis on the possobility of the two to fuse into an insurrectionary or revolutionary people: The people as event (peuple-événement); see Pierre Rosanvallon, Le peuple introuvable: Histoire de la représentation démocratique en France (Paris: Gallimard, 1998), 35-55.
} 
In the political and aesthetic discourse of modernity, this insatiable political desire is typically articulated as a surplus of "flesh" or "mass," which cannot be fitted into any political or social forms of representation. This flesh, this mass, must therefore be continually dissected, disciplined or expelled from the political arena; more specifically, we are speaking about lowerclass masses, Jews, ethnic minorities, immigrants, or "hysteric" females who are separated and excluded each time the polity, or the national community, seeks to become self-identical by attempting to make the people's flesh conform to the representation of the people. Or else, there is always the possibility that the political desire emanating from this surplus explodes in collective protest and destroys established forms of political representation.

The problem is nicely captured in Georg Büchner's 1835 drama The Death of Danton. It contains a monologue in which the revolutionary writer Camille Desmoulins describes the ideal political state in sensual terms. "The state should be a transparent dress that clings to the body of the people. The bulge of every vein, the tensing of every muscle and every sigh of longing must make its impression on it." 31 It is hard to find a better illustration of the politico-theological complex that Santner seeks to understand. At regular intervals from 1789 to 1989 and onwards we see burst forth an irrepressible desire of people to find a shape for their society, a representative, a sovereign leader who does not turn against them like a hostile power. But since each form of political representation tends in time to stiffen and become a straitjacket or iron cage, rebellions will naturally succeed each other, like the pulse of history.

Modernity, Santner states, is driven by energy generated by these conflicts, in which each piece and part of humanity can claim an investment in a democratic transcendence that must not be allowed to attain political form. If Santner is right, we must conclude that democracy-as we usually understand it - always falls short of its own concept because it is unable to dissociate itself from a politico-theological notion, inherited from monarchy, that posits the political as a sphere of transcendental representation. Does this imply that democracy is incompatible with representation as such? Yes, this is what Santner argues-and like so many other critical political theorists today, he argues for an alternative conception of democracy.

\footnotetext{
${ }^{31}$ Georg Büchner, Dantons Tod. Ein Drama, in Werke und Briefe, ed. Franz Josef Görtz (Zürich: Diogenes Verlag, 1988), 26.
} 
This argument resonates with the question concerning the unclear place of collective protests in history. In the light of Santner's theory, collective protests cannot be inserted as meaningful elements in the text of history because they constitute a negation of established ways of representing political subjects and communities. This also explains why revolts are frequently rendered as moments of chaos, disorder, lawlessness and anarchy, which in turn clarifies why historiography often presents collective protest as though it played out in another dimension, above, underneath or beside "real history." As long as history is understood as a complex of representations of social, economic and political agents and causes, collective protest cannot but appear as a monstrous reaction formation to an established status quo. If the table is turned, however, we realize that what is secondary and reactive in relation to the historical process are precisely these very political and cultural representations, whereas the people's surplus of "flesh" and "desire," its monstrous materiality, is primary, or even primordial.

\section{The Witness and the Participant}

If we discard this epistemology of representation, how can we move protest and revolt - the popular surplus - into the realm of knowledge and discourse? Let me now approach this problem. The function of protest is to voice a dissident opinion, an objection. However, protestari, which is the Latin root of the word, contains an additional meaning. It puts the prefix pro- in front of the verb testari, which means "to witness." This etymology hints at an alternative understanding of collective protest, an understanding founded in the participants' act of witnessing.

Historians and social scientists who seek to understand collective protest are here faced with a choice. According to anthropologist Stanley Tambiah, theories of crowd behavior would lose much of their relevance if we subscribed to an epistemology emphasizing participation rather than observation and causal explanation. The latter implies "affective impartiality and abstraction in relation to the events of the world." By contrast, and as Tambiah argues in alluding to Durkheim, the attitude of participation is "present when persons, groups, animals, places and natural phenomena are seen as being in a relation of contiguity" and when this is translated into a relation of "existential immediacy, contact, and community."

\footnotetext{
32 Stanley J. Tambiah, Leveling Crowds: Ethnonationalist Conflicts and Collective Violence in South Asia (Berkeley and Los Angeles: University of California Press, 1996), 306.
} 
Similarly, Hans-Ulrich Gumbrecht has dismissed the "reduction of complexity" inherent in an epistemology that absolutifies the subject as an observer of the world. ${ }^{33}$ This epistemological framework presupposes a human agent who does not participate in history but surveys it von oben. The framework is so deeply ingrained that most Western definitions of knowledge and ethics rely on it: before knowledge can be asserted or judgments made, the world must first be transformed into a representation, what Heidegger called a "world picture." Against such a "Subjektskultur," which decodes reality as a flow of signifiers, Gumbrecht posits "Präsenzkultur," a culture of presence characterized by particular embodied and affective experiences of solidarity, emancipation and temporality. Simply stated, Tambiah and Gumbrecht enable us to oppose two viewpoints. Collective protest is exhibited either as a complex of causes and representations which a subject "views" and analyzes, as on a screen or sheet of paper, or as a piercing event which releases the popular surplus of materiality, affect, and "flesh," as something that gets under the skin or can be known only by exposing one's mind and body to it. ${ }^{34}$

These distinctions are not original. In different guises, they show up in most social sciences and humanities, as they refer back to the general division between analyses that seek to explain and those that seek to understand. The distinction is often activated in historiography, for instance when a historian re-animates the archives in order to give voice to the common men and women who were exposed to the brutal forces of history. In the case of the Holocaust, most scholars would probably agree that its history cannot be conveyed without privileging the voices of those who suffered. The same often applies to war history, where readers are invited to understand the cruelty or excitement of war by way of historical texts that seek to reconstruct the sensory and emotional experience of the individual soldier, or by quoting from the diary or letters that he wrote. This method is seen as necessary, it is argued, if we strive for "true" understanding; truth being linked to the lived experience of an event, which appears to and is conveyed by the individual through the senses, and which therefore is aesthetically mediated. Interestingly, it appears that this method is far more rarely applied to the history of revolts and revolutions. Hence the precise, methodological choice that, as I argue, would bring us closer to a theory of collective protest and political emergence more generally: to attend to the participants'

\footnotetext{
${ }^{33}$ Hans-Ulrich Gumbrecht, "In eine Zukunft gestoßen; Nach dem 11. September 2001," Merkur 55 (November 2001), 1048-1054.

${ }^{34}$ Gumbrecht, "In eine Zukunft gestoßen," 1052f.
} 
phenomenological and sensory experience of collective insurrection with the same historical Einfühlung as elsewhere given the experience of a soldier or a victim of totalitarian tyranny. ${ }^{35}$

Let me now demonstrate in more detail what kind of knowledge there is to gain by recording and reconstruing the experience and immediacy of collective protest? My first example is Elias Canetti's account of the workers' revolt in Vienna on July 15, 1927, which was suppressed by police forces and killed some ninety demonstrators and bystanders.

"It was the closest thing to a revolution that I have physically experienced. Since then, I have known quite precisely that I would not have to read a single word about the storming of the Bastille," Canetti writes in his memoirs. ${ }^{36}$ One feature of Canetti's account is precisely this distinction between what you learn from history books and what you learn through participation. Apparently, Canetti does not need to read about revolts; he has been doing revolt. For him, a mass protest is the very opposite of a representation: an event that etches itself into his mind as a memory that carries the authority of truth. Canetti needs no historical explanation to truthfully account for the protest. Rather, he applies an analysis of affects and experiences, precisely of the kind that he developed in the famous introductory chapter to his monumental work Crowds and Power (Masse und Macht). In his analysis, knowledge about mass behavior is inseparable from corporeal and sensory experience. ${ }^{37}$ As he states in his memoirs: the feeling of the protest "is still in my bones." 38

Another striking feature in Canetti's account is that the protest breaks out of chronology and establishes itself permanently as an existential force that follows life like a shadow. "It was the most unambiguous day that I can remember," he writes about the July uprising. ${ }^{39}$ He recalls the slightest detail. His description attributes to the collective protest a mode of temporality that we may describe as an atemporal present, or a past present which at any time can be recalled and

\footnotetext{
${ }^{35}$ See Ginzburg, Threads and Traces: True, False, Ficitive (Berkeley and Los Angeles: University of California Press, 2012); Shoshana Felman and Dori Laub, Testimony: Crises of Witnessing in Literature, Psychoanalysis, and History, (New York: Routledge, 1992); Horace Engdahl, ed., Witness Literature: Proceedings of the Nobel Centennial Symposium (New Jersey: World Scientific, 2002).

${ }^{36}$ Elias Canetti, The Torch in My Ear, trans. Joachim Neugroschel (New York: Farrar, Straus and Giroux, 1999), $300,484-5$.

${ }^{37}$ Elias Canetti, Crowds and Power, trans. Carol Stewart (New York: Farrar, Straus and Giroux, 1984) (reprint), $15-92$.

${ }^{38}$ Canetti, The Torch in My Ear, 484.

${ }^{39}$ Canetti, The Torch in My Ear, 486.
} 
revived. In this sense, the event is a universal singularity. The protest is exceptional, outstanding, stands out as unique, yet carries a common validity.

A third feature is that this singular phenomenon lacks spatial demarcations. The protest, Canetti argues, is everywhere. The day of revolt was thus "an outspread day, stretching across an entire city." As for himself, he rushed around "all over Vienna." Yet, he also states that his senses "were all focused in one direction." 40 The protest is thus maximal expansion, on the one hand, and complete concentration on one focal point, on the other:

This day, which was borne by a uniform feeling (a single, tremendous wave surging over the city, absorbing it: when the wave ebbed, you could scarcely believe the city was still there) - this day was made up of countless details, each one etched in your mind, none slipping away. Each detail exists in itself, memorable and discernible, and yet each one also forms part of the tremendous wave, without which everything seems hollow and absurd..$^{41}$

Another name for this "the tremendous wave" is of course the mass itself, which Canetti went on to study for the main part of his intellectual life. However one seeks to represent the mass, or "the wave," it obviously evades every form of representation; it appears as a material phenomenon in its own right, as "the flesh" of the people. The protest can therefore be recorded in every detail and sensory impression, it is present in each part of the multitudinous whole, while it at the same time possesses a unity that can be condensed into one point. This point is Vienna's burning Justizpalast, the Palace of Justice, the goal and target of the demonstrations. Fire - above all else a building in flames - is for Canetti a major "crowd symbol," an ambiguous emblem for the destructive power of the protest and at the same time for the liberation from every institutional representation.

The wave is detectable in my second example as well. Jurko Prochasko, a psychotherapist by profession, participated in the protests on Maidan, the Square of Independence, in Kiev during the winter of 2014. His testimonial, recorded by Marci Shore, is perhaps even more remarkable:

\footnotetext{
${ }^{40}$ Canetti, The Torch in My Ear, 486.

${ }^{41}$ Canetti, The Torch in My Ear, 488.
} 
I had understood that dynamic, why people want revolution, why they make revolution, why they cannot do otherwise, why they devote themselves [...]. But I had not understood one thing - for me this was the limit of my own experience-I had not understood the moment when a person is ready to die. And there I understood it. ... it's a departure, a movement beyond the confines of the self, when you experience being with people who are ready to die for you, to make themselves vulnerable for you, to carry you if you're wounded ... a willingness appears - it's a kind of rapture, a wonder at the possibilities given to man, an enormous gratitude to others, simply a Begeisterung with generosity and devotion. And an experiencing of an enormous solidarity [...]. I'm not speaking about whether this is good or bad-that's not the question. The question is not whether this is extremism, or whether it's not extremism, or whether it would have been better to have kept the revolution nonviolent. This is simply phenomenological, it has to be understood, because otherwise we will have understood nothing about revolution. Nothing. ${ }^{42}$

Prochasko says nothing about the official and, as it were, objective goal of the Maidan protests, to bring Ukraine a step or two closer to Europe and the euro. What he describes is beyond representation; participation is here a political act in its own right. The meaning of the protest is sustained as long as the many are present together, close to each other, sharing one and the same social and existential place. Prochasko interprets this togetherness both as a "being in common" and as a "being in the common"; he also expresses it as a boundless solidarity that lasts to the death. Canetti describes a similar experience: "I ran with the others. I sensed that I had to run with them. I wanted to flee into a doorway, but I couldn't get away from the running throng." 43

Such statements offer a glimpse of an aspect of masses and collective protests that Sigmund Freud once theorized. ${ }^{44}$ All collectives, so Freud argued, are essentially held together by relations of love. This statement has in turn given rise to a long line of inquiry, often thrown together as affect theories, in which love, sympathy and solidarity appear as the very content and meaning of protesting collectives. In this context belongs Eric Santner's theory about the

\footnotetext{
${ }^{42}$ Marci Shore, The Ukrainian Night: An Intimate History of Revolution (New Haven: Yale University Press, 2017), 125.

${ }^{43}$ Canetti, The Torch in My Ear, 487.

${ }^{44}$ Sigmund Freud, Mass Psychology and Analysis of the 'I, ' in Freud, Mass Psychology and Other Writings, trans. J. A. Underwood (London: Penguin, 2004), 31.
} 
libidinal investments operating in the gap between the people's two bodies. In this context we also find Antonio Negri and Michael Hardt. "Have you ever noticed that at the great political demonstrations love is in the air?" asks Hardt. This is not to do with any erotic charge, he underlines, but with "a properly political feeling of love. We recognize together what we share in common, what power we have together, what we can do with each other." 45 Another one belonging to this line is George Katsiaficas, student of Herbert Marcuse, whose theory of the so-called Eros Effect designates "the transcendental qualities of social movements" that emerge "as sudden popular protests transform the established social order." 46

While these "erotic" theories of insurrection have their blindnesses as well as their insights, testimonial accounts from large collective political protests often serve to verify the existence of such sympathy, or "enormous solidarity," to use the words of Prochasko. Solidarity, in turn, enables the protesting collective to do (for a while) without political superstructures. As long as everyone's desires are "all focused in one direction" the collective can do without representatives and spokespersons. In this sense, a protesting collective amounts to a democratic subjectivity that constitutes a historical objectivity in its own right. This explains also why it can do without a leader. "For one whole day, I watched a crowd that had formed without a leader," writes Canetti. "Now and then, very seldom, there were people, orators, giving speeches that supported the crowd. Their importance was minimal, they were anonymous, they contributed nothing to the formation of the crowd."47

A protesting collective produces whatever leaders it needs for the purposes at hand, and when they are no longer needed they sink back into the collective - such is the view as conveyed by the witness. ${ }^{48}$ During the popular protests in Cairo in February 2011, there was one question journalists never tired of asking demonstrators on the Tahrir Place: But where are your spokespersons; don't you have any leaders? The answers they got were not in any way coordinated but always conveyed the same basics: When the people act in common there is no need for leaders. "What distinguished our revolution was that its leadership remained

\footnotetext{
${ }^{45}$ Michael Hardt, "Bathing in the Multitude," in Jeffrey T. Schnapp and Matthew Tiews, eds, Crowds (Stanford: Stanford University Press, 2006), 35.

${ }^{46}$ George N. Katsifiacas, "The Eros Effect," Paper prepared for a presentation at the 1989 American Sociological Association National Meetings in San Francisco, manuscript; Katsifiacas, The Imagination of the New Left: A Global Analysis of 1968 (Boston: South End Press, 1987). See also Jason Del Gandio, "Extending the Eros Effect: Sentience, Reality, and Emanation," New Political Science 36/2 (2014): 129-148.

${ }^{47}$ Canetti, The Torch in my Ear, 489.

${ }^{48}$ On the leaderless character of the Occupy movement, see Bernard Harcourt, "Political Disobedience," in Harcourt, Mitchell, and Taussig, Occupy.
} 
anonymous and hardly visible," writes Malek Sghiri about Tunisia's Jasmine Revolution just months before. ${ }^{49}$

In a widespread commentary to the Cairo uprisings, Judith Butler spoke of "the interval" to designate the liberated time of popular protest. As long as the community of protesters remains, it destroys historical time and establishes its own temporality. The time of the interval is therefore "the time of the popular will," Butler continued. However, the popular will is not unified, but performative, the product of many persons' singular ways of appropriating what is common. Butler asks how to best describe this way of acting in common: "Such an action reconfigures what will be public, and what will be the space of politics." ${ }^{50}$

According to witness accounts, collective protest and revolt thus also "suspends historical time," to quote the Italian theorist Furio Jesi. "It suddenly institutes a time in which everything that is done has a value in itself, independently of its consequences and of its relations with the transitory or perennial complex that constitutes history." ${ }^{51}$ Jesi argued that the temporality of revolt constitutes a "shelter from historical time in which the collective finds safety." 52 In this safe abode, a person experiences public space as his or her own, and this precisely because it also belongs to everybody else: "only in the hour of revolt is the city really felt as your own city-your own because it belongs to the 'I' but at the same time to the 'others'; your own because it is a battlefield that you have chosen and the collectivity too has chosen; your own because it is a circumscribed space in which historical time is suspended and in which every act is valuable in and of itself, in its absolutely immediate consequences." 53

It is a cliché, of course, to depict the metropolis and its public spaces as the primordial scene of democracy. Witness accounts often display peculiar blends of commonplace and existential intensity. Numerous commentators have remarked that the protests of 2011 and after have often been about occupying a physical place, however limited, and to turn that place-Zucotti Park,

\footnotetext{
${ }^{49}$ Malek Sghiri, "Greeting to the Dawn: Living through the Bittersweet Revolution," in Layla al-Zubadi, Matthew Cassel and Craven Roderick, eds, Diaries of an Unfinished Revolution: Voices from Tunis to Damascus, (New York: Penguin, 2013), 45.

${ }^{50}$ Judith Butler, "Bodies in Alliance and the Politics of the Street," European Institute for Progressive Cultural Policies, eipcp, no. 10, 2011. Available at: eipcp.net/transversal/1011/butler/en [accessed 12 February 2018]. This argument was later developed in Butler's Notes Toward a Performative Theory of Assembly (Cambridge: Harvard University Press).

${ }^{51}$ Jesi, Spartakus, 46.

${ }^{52}$ Jesi, Spartakus, 53.

${ }^{53}$ Jesi, Spartakus, 54-55.
} 
Gezi Park, Syntagma, Maidan, Tahrir-into a model for democratic renewal and reform by opening up a space for participation, dialogue and agonism. ${ }^{54}$ In this context, Butler is not the only commentator to refer to Hannah Arendt's analysis of the origins of the political arena and the political citizen. Arendt compared these origins to an "appearance" through which the reality of social bonds and social power first announces itself to the members of a society. This is what Arendt called the "space of appearance":

It is the space of appearance in the widest sense of the word, namely, the space where I appear to others as others appear to me, where men exist not merely like other living or inanimate things but make their appearance explicitly. [...] The space of appearance comes into being wherever men are together in the manner of speech and action, and therefore predates and precedes all formal constitution of the public realm and the various forms of government [...]. Its peculiarity is that, unlike the spaces which are the work of our hands, it does not survive the actuality of the movement which brought it into being, but disappears not only with the dispersal of men [...] but with the disappearance or arrest of the activities themselves. Wherever people gather together, it is potentially there, but only potentially, not necessarily and not forever. ${ }^{55}$

The space of appearance is created by speech and action as interlinked modalities of human performance. ${ }^{56}$ It is a space created by dialogue, we might say, but dialogue as an extension of action. "No other human performance requires speech to the same extent as action," writes Arendt. ${ }^{57}$ Correspondingly, we may see Arendt's space of appearance as the constituent moment of the political community, and in this moment speech and action form a dual modality in which dialogic equality and radical solidarity may be realized. ("I appear to others as others appear to me.") This also implies that the space of appearance is at once a pre-political space and a space that is constitutive of politics ("predates and precedes all formal constitution of the public realm and the various forms of government"). The space of appearance is thus one

\footnotetext{
${ }^{54}$ For a striking analysis of this kind, see Andy Merrifield, The Politics of the Encounter: Urban Theory and Protest under Planetary Urbanization (Athens, GA: The University of Georgia Press, 2013).

${ }^{55}$ Arendt, The Human Condition, 198-9. For comments on Arendt's theory in relation to aesthetics, see Cecilia Sjöholm, Doing Aesthetics with Hannah Arendt: How to See Things (New York: Columbia University Press, 2015); Linda M. G. Zerilli, "'We Feel Our Freedom': Imagination and Judgment in the Thought of Hannah Arendt," in Kompridis, ed., The Aesthetic Turn in Political Thought (London: Bloomsbury, 2015), 29-60; Patchen Markell, "Arendt, Aesthetics, and 'The Crisis in Culture'," in ibid., 61-88.

${ }^{56}$ Arendt, The Human Condition, 179.

${ }^{57}$ Arendt, The Human Condition, 179.
} 
without political boundaries, in which dialogue and solidarity prevails in the unbounded atmosphere of potential democracy.

It is an idealized account, to be sure, but it exposes one end of the spectrum within which it is possible to trace and renew political potentialities through aesthetic interpretation. At the other end of that spectrum, we must deal, as Arendt also knew, with the fact of political violence, and its aesthetic expressions. Given this range, we recognize that spaces of appearance are not just things of the past reminding us of the step from a pre-political to a political epoch, but they may be reopened, as Arendt states, "wherever people gather together." Spaces of appearance name sites of political emergence. Arendt may have disagreed, yet I would argue that the space of appearance is also a space that can be opened by collective action or struggle which enlarges the boundaries of the political arena, thus also changing the political constituency. Moreover, it deserves to be asked whether spaces of appearance, understood in Arendt's metaphorical sense, are also spaces of protest, and whether the history of such spaces is perhaps preserved and makes itself known through a largely unorganized "archive" or "corpus" of aesthetic figurations.

\section{Collective Protest and Aesthetic Knowledge}

At the beginning I raised some questions regarding the ambiguous place of collective protest: internal to history, but external to history writing. These questions can now be given a more precise formulation: does the space of appearance have a history? Does it exist only at the dawn of history, as a kind of natural state of politics? Or does it rather always exist as the beginning of politics, as the possibility of a beginning, or even a new beginning? In Arendt, the space of appearance comes across as the degree zero of society and politics, a space where people share what is common, demarcate social identities and reinvent political order. Once this is accomplished, the space of appearance disappears, as "the movement which brought it into being" has exhausted itself. In such ways, then, collective protest is an instance of the "space of appearance," a modality of speech and action that counteracts the deterioration of politics into administration or tyranny.

This is also why these singular events raise particular claims on the historian or the social scientist. Rather than rendering them as moments of exception, excess, and irrationality, collective protests should be seen as universal singularities, which is perhaps what Nora sought 
to convey by designating them as "monster events." Demonstrating the shortcomings of the current order as well as the features of an alternative one, such monstrous events disclose what I have been calling political emergence.

This may in turn help explain many historians' inclination to treat collective protests as taking place outside history, going beyond history or against history. A history writing that would shoulder its democratic responsibility would be one that would be able to return to such events a measure of historical universality or generality, so as to prevent them from being perceived as exceptions and exaggerations. Instead, they would appear as monstrous, in the specific meaning of the term, that is, as constitutive of another social order, or of another way of experiencing and transforming the social and political world.

I will finally say a few words about the possible significance of such kinds of social history or historical sociology and its reliance on aesthetic knowledge. As I have argued, aesthetic works offer particular ways of recording and responding to moments of political emergence. This is because political emergence, denoting pre-representational or anti-representational modes of collective formation and mobilization, makes itself known mainly in sensory, affective, and performative registers - registers which the social sciences and history rarely apprehend but which are core components of that other mode of knowledge that we call aesthetics. Aesthetic interpretation may therefore be understood as a method by which we are able to approach political emergence and collective protest without having to adopt a representational lens. Instead, we would attend to the ways in which the voice and experience of the participant undergo an aesthetic elaboration and figuration through narrative, form, and image in a process that mediates and preserves the sensory, affective and libidinal dimensions of collective behavior. In this way, it would be possible to assemble the elements of what we may call a poetics of collective protest.

As I have indicated, such a poetics of protest would be able to convey the experience of at least three dimensions that come to the fore in the accounts I quoted from above. First, the solidarity that keeps the members of a collectivity together and makes their actions absolutely meaningful regardless of their consequences. Second, a demand for emancipation from unjust representations of people's political desires. Third, a particular experience of temporality, springing precisely from a feeling of solidarity and an emancipatory thrust that are so strong that they transcend chronological and historical time. 
Hypothetically, we may perhaps regard these three - solidarity, emancipation and an alternative temporality - as aspects of the poetics of collective protest. As aspects, in the sense of Wittgenstein's notion that we "see the world" and "word the world" through aspects. ${ }^{58}$ To offer an example, if we took a closer look at the millions of digital messages and images that have documented collective protests throughout the 2010s, we would no doubt be able to group them, if only in a fragmentary and incomplete way, with respect to these aspects.

\section{Conclusion}

In state-of-the-art research in sociology, history, and political science, collective protests usually make up ruptures in the unfolding of a rather narrow narrative of political democracy. Protests are rendered as popular interventions or interludes in a story about the constitution and transformation of democratic institutions, which are seen as more or less adequate forms of representation of the will of the people. Typical outcomes of such research are histories and investigations of voting rights, political parties, social movements, political organizations, legislative and constitutional assemblies, and parliaments, which are seen as so many organizations, institutions and instruments through which the popular sovereign, that is, the state as an incorporation of the demos has tailored for itself the "transparent dress" that should “cling to the body of the people," as Camille Desmoulins exhorts in Büchner's drama.

The problem, then, is that history and the social sciences have almost exclusively devoted themselves to the dress. All too rarely they have focused on "the body of the people," that shapeless, changeable organism of desire, consisting of millions of members and owning a surplus of "mass" and "flesh" that can only be partially represented, or not at all.

There seems to be a still unwritten history of collectivity as a political body, whose repeated protests constitute another and more fundamental historical temporality, and in which a political subject appears that brings democracy back to its beginnings. This unwritten history has many things in parallel with the project for a "universal history" as envisioned by Susan Buck-Morss, or the idea that universal history emerges from below and from the margins in networks of

\footnotetext{
${ }^{58}$ Ludwig Wittgenstein, Lectures and Conversations on Aesthetics, Psychology and Religious Belief (Oxford: Oxford University Press, 1989).
} 
human solidarity that cut across spatial and temporal boundaries. ${ }^{59}$ In this sense, universal history attends to the "intervals" of chronological history, the interruptions in the calendar of power.

This also explains why collective protest is typically assigned a "monstrous" position outside historical chronology and powered by a sense of solidarity that cannot be channeled by established forms of political and cultural representation. From this ex-centric and ineffable position, which is also the location of the insurrectionary archive, past protests fuel future ones, enchanted by similar projects of democracy and solidarity. Due to the existence of this parallel temporality, made up by narratives, testimonials, artworks and embodied memory ("the dreams of humanity"), collective protest movements can speak to each other across time and space. ${ }^{60}$ Collective protests in the present carry within them, as their condition of possibility, the collective protests of the pasts. Protests therefore usually appear as uncompleted, neither victorious nor vanquished, but undecided, because they are part not of history, but of "becoming," to phrase it in Deleuzian terms. Each subsequent protest will occupy a space of political emergence similar to the previous one and articulate a democratic desire that will connect it to future ones; they thus exist in one and the same political atemporality, which we may call, after Pierre Rosanvallon, "the people as event," or the insurrectionary Jetztzeit after Walter Benjamin. In order to discern this history of collective protest we should complement-and for some purposes replace - the epistemological paradigm that rests on distance, causality, and representation with an epistemology in which knowledge is attained through sensory presence, participation, embodied performativity, and acts of witnessing; what Canetti at the beginning of his political ontology calls the fear and desire of "being touched."

Let me emphasize that this history is important because perhaps it alone can teach us something about the complex dialectics whereby the power to represent, lead, rule, and command is continually and repeatedly undermined by that completely different power which resides in human potentiality, the ability to do, make, transform, and liberate.

I have approached collective protest as a space of political emergence, reflecting on why this space is often occluded in historical accounts. The protest is passed over in silence and the

\footnotetext{
59 Susan Buck-Morss, Hegel, Haiti, and Universal History, Pittsburgh 2009); Buck-Morss, The Dialectics of Seeing: Walter Benjamin and the Arcades Project (Cambridge, MA: The MIT Press, 1989).

${ }^{60}$ Buck-Morss, Hegel, Haiti, 148-151; Dialectics of Seeing, 331-340.
} 
collectivity is expulsed to barely visible non-spaces of history. This is why we need a methodology to understand, retrieve, and respond to "the emancipatory promise" that animates that space. ${ }^{61}$ I have suggested that this space is delivered to us in the encrypted media of aesthetically-rendered testimonials and witness accounts that entail voice, dialogue, embodiment, visibility, and participation. As a final illustration, I give you Arthur Rimbaud's report, composed a year after the Paris Commune: "When will we go, over mountains and shores, to hail the birth of new labor, new wisdom, the flight of tyrants and demons, the end of superstition, to be the first to adore ... Christmas on earth!"62

140 years later Khawla Dunia responds from Damascus: "And the demonstrations go on, into the unknown."63

\footnotetext{
${ }^{61}$ I borrow the phrase from Jacques Derrida, Specters of Marx: The State of the Debt, The Work of Mourning and the New International (London: Routledge, 1994), 74.

${ }^{62}$ Arthur Rimbaud, "Morning," in Rimbaud, Complete Works, trans Paul Schmidt (New York: Perennial Classics, 2000), 242.

${ }^{63}$ Khawla Dunia, "And the Demonstrations Go On," in Diaries of an Unfinished Revolution (New York: Penguin, 2013), 208.
} 